\title{
Природопользование
}

DOI: $10.12737 /$ article_5c1a3218393393.63371536

УДК 631.445.51:630*181.32(470.620)

ЛЕСОПРИГОДНОСТЬ ПОЧВ ТАМАНСКОГО ПОЛУОСТРОВА

доктор сельскохозяйственных наук, профессор А. П. Максименко ${ }^{1}$

кандидат сельскохозяйственных наук, доцент Е. П. Дзябко ${ }^{1}$

кандидат сельскохозяйственных наук Д. В. Максимцов 2

1 - ФГБОУ ВО «Кубанский государственный аграрный университет имени И.Т. Трубилина»,

г. Краснодар, Российская Федерация

2 - Министерство сельского хозяйства и перерабатывающей промышленности Краснодарского края,

г. Краснодар, Российская Федерация

Необходимость создания на Таманском полуострове лесных насаждений многофункционального назначения диктуется сложившейся экологической ситуацией. Лесистость полуострова составляет $1.19 \%$ и является одной из низких на территории Краснодарского края. Площадь земель, вовлеченных в хозяйственный оборот, не превышает 50 \% от общей площади полуострова. Повышение лесистости района улучшит экологическую рекреационную ситуацию и позволит вовлечь в хозяйственный оборот не продуцирующие земли. По развитию почвообразовательного процесса Восточное Приазовье можно разделить на три района. В первый объединяются прибрежные песчано-ракушечные отложения с косами, вдающимися в Азовское море. Эволюция почвообразования здесь происходит под действием гидроаккумулятивных процессов бассейна Азовского моря. Во второй район входят пойменные дельтовые зоны, находящиеся на гидроморфной стадии своего развития. В третий район входит Таманский полуостров. Его ландшафты прошли еще более сложный путь развития и в настоящее время находятся на мезо- и палеогидроморфной стадии и включают элементы ландшафтов первого и второго районов. Разный уровень организации естественных ландшафтов требует и различного подхода к созданию в них искусственных лесонасаждений. Эти насаждения должны соответствовать уровню эволюции почвообразования и вписываться в геохимический ландшафт. Представлены многолетние исследования по изучению критериев лесопригодности почв на Таманском полуострове. Рассматриваются различные параметры оценки лесопригодности. Показаны практические агролесомелиоративные аспекты определения конкретной категории непродуцирующих земель. Приводятся рекомендации основных агротехнических приемов лесовыращивания и сортимента древесных и кустарниковых пород для создаваемых лесонасаждений.

Ключевые слова: ландшафт, биогеоценоз, почвы, засоление, лесонасаждения, растительность, лесопригодность.

\section{FOREST SUSTAINABILITY OF SOIL OF TAMAN PENINSULA}

DSc (Agriculture), Professor A. P. Maksimenko ${ }^{1}$

$\mathrm{PhD}$ (Agriculture), Associate Professor E. P. Dzyabko ${ }^{1}$

$\mathrm{PhD}$ (Agriculture) D. V. Maksimtsov ${ }^{2}$

1 - Federal State Budget Education Institution of Higher Education «Kuban State Agrarian University

named after I.T. Trubilin», Krasnodar, Russian Federation

2 - Ministry of Agriculture and Recycling of the Krasnodar Region, Krasnodar, Russian Federation

\begin{abstract}
The need to create a multi-purpose forest plantation on the Taman Peninsula is dictated by the current environmental situation. The peninsula's forest cover is $1.19 \%$ and it is one of the lowest in the Krasnodar Territory. The land area involved in the economic turnover does not exceed $50 \%$ of the total area of the peninsula. Increasing the area of forest land will improve the ecological recreational situation and will allow non-producing land to be involved in the economic turnover. According to the development of the soil-forming process, the Eastern Azov region can be divided into three regions. Coastal sand and shell sediments are combined in the first one with streamers extending into the Sea of Azov. Evolution of soil formation here occurs under the
\end{abstract}




\section{Природопользование}

effect of hydroaccumulative processes in the basin of the Azov Sea. The second region includes floodplain delta zones that are at the hydromorphic stage of their development. The third area includes the Taman Peninsula. Its landscapes have gone through an even more complex development path and are currently at the meso- and paleohydromorphic stages and include elements of landscapes in the first and second regions. Different level of organization of natural landscapes requires a different approach to creating artificial forests in them. These plantings should correspond to the level of evolution of soil formation and fit into the geochemical landscape. Long-term studies on the criteria for soil suitability on the Taman Peninsula are presented. Various parameters for assessing forest availability are considered. Practical agroforestry melioration aspects of identifying a specific category of non-producing land are shown. The recommendations of the main agro technical methods of forest cultivation and the assortment of tree and shrub species for created trees are given.

Keywords: landscape, biogeocenosis, soils, salinization, afforestation, vegetation, forest sustainability

Почвы Тамани являются в различной степени засоленными или солонцеватыми, щебнистыми смытыми. Они характеризуются очень низкой лесопригодностью, поэтому создавать на них устойчивые, жизнеспособные насаждения стандартными лесокультурными способами не удается. Лесоразведение на таких землях необходимо начинать $\mathrm{c}$ почвеннолитологического обследования, подбора соответствующего ассортимента пород, наиболее соответствующих лесорастительным свойствам почв $[1,2,11]$.

Формирование засоленных почв связано с накоплением солей в грунтовых водах и почвообразующих породах, генезис которых сопряжен с морскими аккумуляциями. При их выветривании образуется значительное количество легкорастворимых солей, которые в условиях жаркого климата сухих степей и непромывного типа водного режима не вымываются из почвы и засоляют ее. Легкорастворимые соли могуг образовываться при извержении вулканов, в том числе и грязевых, ныне действующих на Тамани. Исследуемая территория со всех сторон омывается морями, на ней широко распространены соленые озера и лиманы, с поверхности которых происходит воздушный перенос солей на сушу. Большая роль в аккумуляции водорастворимых солей в почвогрунтах относится к растительности, при которой они попадают в почву после аэробного разложения. И все же основным источником легкорастворимых солей в ландшафтах являются геологические горные породы [3].

Проведенные исследования показали, что разнообразие морфологических и физико-химических свойств почв, запасов в них элементов питания, их мелиоративные возможности в однородных макроклиматических условиях зависят в первую очередь от рельефа и особенностей геологических отложений.
Исходя из этого и была поставлена цель данной работы - выявить почвенные и литологические факторы, лимитирующие продукции-онные процессы на различных отложениях Тамани, с тем чтобы это легло в основу разрабатываемой экологобиологической концеп-ции озеленения и ландшафтного строительства Восточного Приазовья.

Для определения участков, в различной степени пригодных для выращивания лесных культур, было проведено детальное изучение и картирование почв на ключевых опытных участках Таманского стационара. Всего было обследовано 2850 га нелесных почв мелиоратив-ного фонда и проведена группировка их по лесопригодности (табл. 1).

Нами были описаны лесные почвы под естественной дубравой, зональные каштановые почвы на делювиальных глинистых отложениях, слабогумусированные пески в обширной котловине выдувания и маломощные почвы крутых склонов. Лесные культуры на таких почвах имели высокую сохранность.

Главным препятствием для роста древес-ной растительности на Тамани является не генетическая принадлежность почв к тому или иному типу, а климатические показатели и токсичность веществ, содержащихся в почвен-ных породах. Лесной фитоценоз может произрастать при выпотном (с вариантом «болотный»), промывном и периодически промывном типах водного режима, то есть при значениях гидротермического коэффициента (ГТК) от 1 и выше [3]. Количество воды в естественных лесных экосистемах для их устойчивого существования должно быть близким к испаряемости или несколько превышать ее. В связи с этим естественные леса на водоразделах не опускаются южнее лесостепи, а наличие пойменных, байрачных насаждений и лесных массивов на песках в степной 
Таблица 1

Группы лесопригодности почв Таманского полуострова

\begin{tabular}{|c|c|c|c|c|c|c|}
\hline Объект & $\begin{array}{c}\text { Пло- } \\
\text { щадь, га }\end{array}$ & $\begin{array}{c}1 \text { группа- } \\
\text { лесопри- } \\
\text { годные, } \\
\text { га/\% }\end{array}$ & $\begin{array}{c}2 \text { группа - } \\
\text { относительно } \\
\text { лесопригод- } \\
\text { ные, га/\% }\end{array}$ & $\begin{array}{c}\text { 3 группа - } \\
\text { условно ле- } \\
\text { сопригод- } \\
\text { ные, га/\% }\end{array}$ & $\begin{array}{c}4 \text { группа - для } \\
\text { солеустойчи- } \\
\text { вых кустарни- } \\
\text { ков, га/\% }\end{array}$ & $\begin{array}{c}\text { 5 группа - не- } \\
\text { лесопригод- } \\
\text { ные, га/\% }\end{array}$ \\
\hline Мирный & 189,5 & $53,8 / 28,4$ & $-/-$ & $-/-$ & $16,2 / 8,5$ & $119,5 / 63,1$ \\
\hline Прогресс & 77,4 & $9,5 / 12,3$ & $28,1 / 36,3$ & $13,0 / 16,8$ & $6,2 / 8,0$ & $20,6 / 26,6$ \\
\hline Южная & 1206,9 & $299,6 / 24,8$ & $256,7 / 21,3$ & $278,8 / 23,1$ & $160,9 / 13,3$ & $210,0 / 17,5$ \\
\hline Янтарь & 591,0 & $152,5 / 25,8$ & $38,9 / 6,6$ & $130,0 / 22,0$ & $30,6 / 5,2$ & $239,0 / 40,4$ \\
\hline Победа & 433,7 & $33,4 / 7,7$ & $47,1 / 10,9$ & $6,2 / 1,4$ & $148,4 / 34,2$ & $198,6 / 45,8$ \\
\hline Черноморец & 75,0 & $-/-$ & $-/-$ & $-/-$ & $4,5 / 6,0$ & $70,5 / 94,0$ \\
\hline Восход & 276,6 & $-/-$ & $102,5 / 37,0$ & $92,5 / 33,4$ & $-/-$ & $81,6 / 29,5$ \\
\hline Всего & 2850,1 & $548,8 / 19,3$ & $473,3 / 16,6$ & $520,5 / 18,3$ & $366,8 / 12,9$ & $940,7 / 33,0$ \\
\hline
\end{tabular}

зоне с ГТК близким к 0,25 нами объясняется локальным поступлением влаги в элементарные элементы ландшафта.

Следовательно, концептуальное решение проблемы озеленения и ландшафтного строи-тельства на Таманском полуострове должно основываться не на полосном размещении лесных культур, а на организации ландшафтно-геохимических и биоценотических каскадных систем, учитывающих особенности рельефа $[5,9,10]$.

На водоразделах и верхних частях склонов, где начинается водный и гидро-химический сток, должны создаваться централь-ные ядра, которые будут управлять данной биогеоценотической каскадной системой по аналогии с уникальным естественным явлением урочищем Дубовый Рынок. И чем сложнее получится насаждение, тем лучше оно будет выполнять функции организации центра и, наряду с регулированием жидкого и твердого стока, должно будет проявлять барьерные функции по отношению к химическим элементамбиофилам и надежно удерживать их в биологическом круговороте, тем самым предохраняя их от выноса за пределы данного биогеоценоза.

Внизу склонов, балок, оврагов и на других изменениях рельефа должны создаваться вспомогательные звенья биогеоценотических систем. В зависимости от состава поступающих с гидрохимическими стоками элементов могут использоваться виды-накопители кальция, кремнезема, галогенов из основного ассортимента пород.

Вспомогательные биогеоценозы мобилизуют азот, фосфор, калий, образованные на месте и поступающие со стоком. Значит, данные насаждения должны выполнять барьерные и буферные функции и повышать биопродуктивность ландшафта [11].

Поэтому при облесении лесопригодных участков большое внимание было уделено исследованию почв транзитно-аккумулятивных и аккумулятивных звеньев каскадной геохимической цепи, в том числе и овражно-балочным местообитаниям.

Ниже приводится характеристика почв мелиоративного фонда Тамани по лесопригодности [7].

I группа - лесопригодные почвы мелиоративного фонда. Из обследованных при картировании 2850 га почв лесопригодными (то есть отвечающими вышеперечисленным критериям) оказались 548,8 га, или 19,3 \% площади, причем их массивы приходятся на территории агрофирм «Южная» и «Янтарь».

Эти участки приурочены к волнисто-увалистым и высоким плоским берегам Черного и Азовского морей, широким балкам, узким прибрежным полосам, окаймляющим озеро Соленое, лиманы Кизилташский, Ахтанизовский и Цокур, склоны гор Макитра, Лысая, Раскопанная, Карабетка, Комендантская, Близнецы и др. и прорезывающим их оврагам и балкам, а также крутым, местами обрывистым, с оползнями берегам Таманского полуострова к омывающим его морям.

Из отведенных под лесные мелиорации участков пригодными для выращивания на Тамани являются: песчаноракушечные отложения, пески слабогумусированные, маломощные и делювиальные почвы склонов, каштановые и луговокаштановые почвы, а 


\section{Природопользование}

также почвы овражно-балочного комплекса.

\section{Каштановые почвы}

Данная типологическая группа располагается в основном ближе к водоразделам и волнисто-увалистым грядам, а также их склонам. Находится, в основном, под виноградниками и овощными севооборотами. Лесные насаждения располагаются на узких краевых участках высоких берегов Черного моря и Таманского залива.

Почвы каштановые карбонатные глинистые на бурых глинах характеризуются тяжелым механическим составом всего профиля с высоким содержанием ила. Это ухудшает их пористость, ухудшает качествен- ное распределение воздуха, влаги и тепла.

Почва с объёмной плотностью более 1,25 г/ $\mathrm{cm}^{3}$ и пористостью 35-40 \% считается сильно уплотненной, трудно проницаемой для корней древесных растений. Верхние, перегнойно-аккумулятивные горизонты данных почв содержат от 2,1 до 2,8 \% (92-123 т/га) гумуса (табл. 2)

Вниз по профилю эта величина стремительно снижается и составляет в иллювиальном слое 0,60,8 \%. При этом содержание фосфора низкое, а калия высокое. Большая дисперсность почв, их щелочная реакция способствует увеличению емкости катионного обмена, насыщению почвенного поглощающего ком-

Таблица 2

Химические и химико-физические свойства каштановых глинистых почв

\begin{tabular}{|c|c|c|c|c|c|c|c|c|c|}
\hline \multirow{2}{*}{$\begin{array}{c}\text { № раз- } \\
\text { реза }\end{array}$} & \multirow{2}{*}{$\begin{array}{c}\text { Глубина } \\
\text { забора } \\
\text { проб, см }\end{array}$} & \multirow{2}{*}{$\begin{array}{c}\text { Гумус, \% } \\
\text { (по Тю- } \\
\text { рину) }\end{array}$} & \multirow{2}{*}{\multicolumn{2}{|c|}{\begin{tabular}{c|c}
$\mathrm{P}_{2} \mathrm{O}_{5}$ & $\mathrm{~K}_{2} \mathrm{O}$ \\
\multicolumn{2}{c}{ мг/100 г } \\
почвы (по \\
Мачигину)
\end{tabular}}} & \multirow{2}{*}{$\begin{array}{c}\text { pН вод- } \\
\text { ной вы- } \\
\text { тяжки }\end{array}$} & \multirow{2}{*}{$\begin{array}{c}\text { Ёмкость по- } \\
\text { глощения, } \\
\text { мг-экв./ } 100 \text { г } \\
\text { почвы }\end{array}$} & \multicolumn{2}{|c|}{$\begin{array}{c}\text { Обменный } \\
\text { натрий }\end{array}$} & \multirow{2}{*}{$\begin{array}{c}\text { Плотный } \\
\text { остаток, \% }\end{array}$} \\
\hline & & & & & & & $\begin{array}{l}\text { мГ- } \\
\text { экв. }\end{array}$ & $\%$ & \\
\hline \multicolumn{10}{|c|}{$\mathrm{a} / \phi \ll$ «обеда» } \\
\hline \multirow[t]{5}{*}{19} & $0-30$ & 2,8 & 15,0 & 80,0 & 7,7 & 25,2 & 0,3 & 1,2 & 0,134 \\
\hline & $40-50$ & 1,4 & 6,0 & 80,0 & 8,1 & 27,3 & 0,5 & 2,7 & 0,104 \\
\hline & $60-70$ & 1,0 & 6,6 & 80,0 & 8,6 & & & & 0,142 \\
\hline & $100-110$ & 0,6 & 3,0 & 40,0 & 9,0 & & & & 0,184 \\
\hline & $140-150$ & 0,5 & 2,5 & 20,0 & 8,7 & 29,4 & & & 0,278 \\
\hline \multicolumn{10}{|c|}{$\mathrm{a} / \phi$ «Южная» } \\
\hline \multirow{5}{*}{$6 a$} & $0-30$ & 2,0 & 1,6 & 23,0 & 8,0 & 35,7 & 0,7 & 1,9 & 0,092 \\
\hline & $35-45$ & 1,5 & 0,3 & 15,5 & 8,3 & 34,0 & 1,0 & 2,8 & 0,104 \\
\hline & $50-60$ & 1,3 & 0,2 & 12,5 & 8,3 & & & & 0,076 \\
\hline & $110-120$ & & & & 8,3 & & & & 0,126 \\
\hline & $140-150$ & & & & 8,2 & & & & 0,156 \\
\hline \multirow{5}{*}{$3 a$} & $0-20$ & 2,7 & 0,9 & 40,0 & 8,1 & 35,7 & 0,8 & 2,2 & 0,082 \\
\hline & $30-40$ & 0,8 & 0,4 & 19,5 & 8,1 & 29,4 & 0,6 & 2,0 & 0,076 \\
\hline & $50-60$ & 0,7 & 0,4 & 18,0 & 8,4 & & & & 0,092 \\
\hline & $120-130$ & & & & 8,5 & & & & 0,064 \\
\hline & $150-170$ & & & & 8,5 & & & & 0,080 \\
\hline \multirow{5}{*}{68} & $0-30$ & 2,1 & 0,5 & 15,5 & 8,0 & 29,4 & 0,5 & 1,7 & 0,076 \\
\hline & $40-50$ & 1,6 & 0,4 & 13,0 & 8,1 & 25,2 & 0,4 & 1,6 & 0,056 \\
\hline & $70-80$ & 0,8 & 0,3 & 18,0 & 8,3 & & & & 0,060 \\
\hline & $110-120$ & & & & 8,7 & & & & 0,040 \\
\hline & $140-150$ & & & & 8,8 & & & & 0,060 \\
\hline
\end{tabular}




\section{Природопользование}

плекса основаниями, при этом 1,2-2,8 \% от их суммы приходится на натрий, который поглощается коллоидами лишь при значительном их содержании в почвенном растворе. Натрий увеличивает щелочность и отрицательно влияет на состояние коллоидов и ростовые функции растений. Потому почвы верхних частей гряд, ассоциированных с засоленными участками, содержащие более высокие концентрации натрия, свыше 3-4 \% от ёмкости поглощения, не могут быть отнесены к пригодным для выращивания.

Отсутствие легко растворимых солей в токсичных количествах (плотный остаток менее 0,3 \%) позволяет использовать данные почвы под лесонасаждения большинства древесно-кустарниковых пород.

II группа - относительно лесопригодные лугово-каштановые почвы.

Почвы второй почвенно-типологической группы описаны нами вдоль берега озера Соленого и в нескольких неглубоких балках. Они отличаютсяот каштановых более темной окраской верхних, перегнойноаккумулятивных горизонтов, более легким механическим составом и большей влагоёмкостью почвенного профиля, где нами не обнаружено видимых скоплений легкорастворимых солей.

По химическим и физикохимическим свойствам данные почвы не содержат в профиле легкорастворимые соли (табл. 3). Обменный натрий не превышает $1,5 \%$ ёмкости катионной части почвенного поглощающего комплекса, не влияет на технологические свойства почв. Поэтому у нас есть основание рекомендовать использовать луговокаштановые почвы на Тамани для создания сложных по форме, смешанных по составу насаждений из древеснокустарниковых видов основного и дополнительного районированного списка, и даже самых требовательных.

Маломощные почвы крутых склонов составляют третью группу почв. Встречаются на крутых склонах побережья и берегах лиманов.

Склоны горы Макитра отличаются от берегов лимана Цокур более легким гранулометрическим составом и четкой дифференциацией на почвенные слои с различным сочетанием слагающих элементов. Более тяжелые прослойки выполняют в ландшафте отражающие, барьерные функции по отношению к переноси-мым с водными потоками веществам и разрушающей энергии, изменяют направление их движения с нисходящего на латеральное, с напочвенного во внугрипочвенное. Следовательно, проектирование в данных условиях должно предусматривать введение в структуру насаждений полос поперек склонов, древесных и

Таблица 3

Химические и химико-физические свойства лугово-каштановых почв

\begin{tabular}{|c|c|c|c|c|c|c|c|c|c|}
\hline \multirow{2}{*}{$\begin{array}{c}\text { № pa3- } \\
\text { реза }\end{array}$} & \multirow{2}{*}{$\begin{array}{c}\text { Глубина } \\
\text { забора } \\
\text { проб, см }\end{array}$} & \multirow{2}{*}{$\begin{array}{c}\text { Гумус, } \\
\text { \% (по } \\
\text { Тюри- } \\
\text { ну) }\end{array}$} & $\mathrm{P}_{2} \mathrm{O}_{5}$ & $\mathrm{~K}_{2} \mathrm{O}$ & \multirow{2}{*}{$\begin{array}{c}\text { pН вод- } \\
\text { ной вы- } \\
\text { тяжки }\end{array}$} & \multirow{2}{*}{$\begin{array}{c}\text { Ёмкость } \\
\text { поглощения, } \\
\text { мг-экв./ } \\
100 \text { г почвы }\end{array}$} & \multicolumn{2}{|c|}{$\begin{array}{c}\text { Обменный } \\
\text { натрий }\end{array}$} & \multirow{2}{*}{$\begin{array}{l}\text { Плотный } \\
\text { остаток, \% }\end{array}$} \\
\hline & & & \multicolumn{2}{|c|}{$\begin{array}{l}\text { мг/100 г почвы } \\
\text { (по Мачигину) }\end{array}$} & & & МГ-ЭКВ. & $\%$ & \\
\hline 1 & 2 & 3 & \multicolumn{2}{|c|}{4} & 5 & 6 & 7 & 8 & 9 \\
\hline \multicolumn{10}{|c|}{ a/ф «Янтарь» } \\
\hline \multirow{5}{*}{28} & $2-12$ & 2,9 & 2,3 & 20,5 & 7,6 & 21,0 & 0,25 & 1,2 & 0,124 \\
\hline & $20-30$ & 1,6 & 0,5 & 9,0 & 7,8 & 21,0 & 0,28 & 1,3 & 0,064 \\
\hline & $50-60$ & 1,3 & 0,3 & 8,0 & 8,2 & & & & 0,760 \\
\hline & $90-100$ & & & & 7,5 & & & & 0,112 \\
\hline & $150-160$ & & & & 9,2 & & & & 0,144 \\
\hline \multirow{6}{*}{25} & $0-27$ & 3,4 & 1,1 & 31,0 & 8,0 & 29,4 & 0,45 & 0,28 & \\
\hline & $30-40$ & 2,2 & 0,5 & 13,0 & 8,2 & 29,4 & 0,18 & 0,60 & 0,142 \\
\hline & $60-70$ & 2,1 & 0,4 & 12,5 & 8,3 & & & & 0,108 \\
\hline & $80-90$ & & & & 8,6 & & & & 0,108 \\
\hline & $120-130$ & & & & 9,1 & & & & 0,090 \\
\hline & $160-170$ & & & & 9,1 & & & & 0,150 \\
\hline
\end{tabular}




\section{Природопользование}

кустарниковых видов с поверхностной корневой системой: робиния, облепиха и другие виды. В этом случае можно более полно и эффективно использовать почвенную среду и усилить барьерный потенциал насаждения для защиты от эрозии.

Почвы отрогов горы Макитра, которые сложены супесями и легкими суглинками, содержат мало ила, от 7 до 14 \%, поэтому обладают невысокой ёмкостью обмена и малыми запасами основных органогенов (табл. 4). При увеличении содержания ила и физической глины происходит увеличение насыщения поч- венного поглощающего комплекса кальцием и магнием, что улучшает структуру почвы, оптимизирует окислительновосстановительный потенциал и улучшает условия произрастания лесных насаждений.

Реакция среды остается щелочной для всех почвенных слоёв, что, видимо, связано с молодостью данных ландшафтов и формированием известкованной коры выветривания.

При создании насаждений на крутых склонах, сложенных легкими породами, следует использовать как примерную модель насаждения урочищ Ибрагимов

Таблица 4

Химические и химико-физические свойства почв крутых склонов Таманского полуострова

\begin{tabular}{|c|c|c|c|c|c|c|c|c|c|}
\hline \multirow{2}{*}{$\begin{array}{c}\text { № pa3- } \\
\text { реза }\end{array}$} & \multirow{2}{*}{$\begin{array}{c}\text { Глубина } \\
\text { забора } \\
\text { проб, см }\end{array}$} & \multirow{2}{*}{$\begin{array}{c}\text { Гумус, \% } \\
\text { (по Тю- } \\
\text { рину) }\end{array}$} & $\mathrm{P}_{2} \mathrm{O}_{5}$ & $\mathrm{~K}_{2} \mathrm{O}$ & \multirow{2}{*}{$\begin{array}{c}\text { pН вод- } \\
\text { ной вы- } \\
\text { тяжки }\end{array}$} & \multirow{2}{*}{$\begin{array}{c}\text { Ёмкость по- } \\
\text { глощения, } \\
\text { мг-экв./ } 100 \text { г } \\
\text { почвы }\end{array}$} & \multicolumn{2}{|c|}{$\begin{array}{c}\text { Обменный } \\
\text { натрий }\end{array}$} & \multirow{2}{*}{$\begin{array}{c}\text { Плотный } \\
\text { остаток, \% }\end{array}$} \\
\hline & & & \multicolumn{2}{|c|}{$\begin{array}{c}\text { мг/100 г } \\
\text { почвы (по } \\
\text { Мачигину) }\end{array}$} & & & $\begin{array}{l}\text { МГ- } \\
\text { ЭКв. }\end{array}$ & $\%$ & \\
\hline \multicolumn{10}{|c|}{$\mathrm{a} / \phi \ll$ «нтарь» } \\
\hline \multirow{5}{*}{72} & $0-23$ & 0,7 & 1,0 & 10,5 & 7,3 & 8,4 & 0,18 & 2,1 & 0,052 \\
\hline & $30-40$ & & & & 7,5 & 10,5 & 0,08 & 0,8 & 0,066 \\
\hline & $45-55$ & & & & 7,5 & & & & 0,066 \\
\hline & $70-80$ & & & & 7,8 & & & & 0,060 \\
\hline & $80-90$ & & & & 7,8 & & & & 0,044 \\
\hline \multirow{5}{*}{73} & $0-25$ & 2,1 & 4,8 & 25,5 & 7,1 & 16,8 & 0,38 & 2,3 & 0,058 \\
\hline & $30-40$ & & & & 7,2 & 17,7 & 0,08 & 0,5 & 0,032 \\
\hline & $50-60$ & & & & 7,6 & & & & 0,064 \\
\hline & $90-100$ & & & & 7,6 & & & & 0,082 \\
\hline & $140-150$ & & & & 8,3 & & & & 0,042 \\
\hline \multirow{5}{*}{59} & $0-26$ & 2,1 & 3,0 & 55,0 & 8,2 & 23,1 & 0,28 & 1,2 & 0,088 \\
\hline & $30-40$ & 1,8 & 2,2 & 28,0 & 7,8 & 23,1 & 0,58 & 2,5 & 0,112 \\
\hline & $50-60$ & 1,8 & 2,0 & 42,5 & 7,8 & 27,3 & 0,28 & 1,0 & 0,170 \\
\hline & $90-100$ & & & & 8,3 & & & & 0,087 \\
\hline & $150-160$ & & & & 8,1 & & & & 0,112 \\
\hline \multirow{5}{*}{71} & $0-23$ & 2,0 & 1,0 & 15,5 & 8,1 & 21,0 & 0,38 & 1,8 & 0,052 \\
\hline & $30-40$ & & & 15,5 & 8,2 & 18,9 & 0,28 & 1,5 & 0,068 \\
\hline & $45-55$ & & & & 8,2 & & & & 0,048 \\
\hline & $70-80$ & & & & 8,4 & & & & 0,060 \\
\hline & $130-140$ & & & & 8,6 & & & & 0,124 \\
\hline \multirow{5}{*}{74} & $0-17$ & 2,1 & 1,3 & & 8,2 & 23,1 & 9,28 & 1,2 & 0,030 \\
\hline & $20-30$ & & & & 8,0 & 23,1 & 0,48 & 2,1 & 0,074 \\
\hline & $40-50$ & & & & 7,9 & & & & 0,084 \\
\hline & $70-80$ & & & & 8,1 & & & & 0,146 \\
\hline & $130-140$ & & & & 8,1 & & & & 0,074 \\
\hline
\end{tabular}




\section{Природопользование}

лес и Сад Яхно и использовать различные комбинации из эндемичных и интродукционных видов растений, долгое время закрепившихся в данных ландшафтах.

В четвертую почвеннотипологическую группу включены почвы овражнобалочного комплекса и делювиальные почвы склонов широких балок. Так как рельеф Таманского полуострова представляет собой наклоненную к северу равнину, рассеченную балками, лощинами, долинами, создание искусственных прибалковых насаждений позволит решить ряд природоохранных мер. Это увеличит биомассу ландшафта и приведет к эмиссии кислорода и депониро-ванию углерода; а также сформирует биологические барьеры на пугях миграции химических веществ и удержит их в биологическом круговороте, организует степные экосистемы, что повлияет на создание в них участков с лесной обстановкой.

Слоистость, обнаруженная по всему профилю, указывает на делювиальный характер отложений, это является основой генезиса таких почв. Процесс переотложения продуктов сноса на склонах сопровождается эрозионными процессами и образованием пролювия. Для предотвращения таких явлений необходимо проводить лесные мелиорации.

На склонах широких балок и оползневых понижений нами выделены делювиальные почвы, достигающие профиля равновесия и не подвергающиеся эрозионным процессам.

Стратегия озеленения этих элементов ландшафта может основываться на использовании возможностей транзита для создания устойчивых и долговечных насаждений. Здесь необходимо использовать древесные виды с поверхностной корневой системой смешанного типа, так как верхняя часть почвенного профиля имеет невысокую щелочность, большую емкость поглощения и наиболее высокие запасы питательных веществ. Содержание гумуса на склонах установлено в пределах 1,1-1,6 \%, а на днищах балок достигает 2,7-2,8 $\%$. Отсугствие засоления подтверждено пониженными показате-лями величины плотного осадка от верхних горизонтов до материнской породы, что под-тверждает пригодность данных типов почв для выращивания лесных культур.

В пятую почвенно-типологическую группу объединяются песчано-ракушечные отложения и слабогумусированные пески.
Песчаноракушечные отложения рас-положены вдоль Азовского побережья, а также на берегу Кизилташского лимана у горы Макитра. Лесорастительные возможности и качественные параметры этих почв нами были описаны на территории Должанского стационара $[5,6]$. Эти почвы были выделены в агрофирме «Южная» у озера Тузла в широкой и глубокой ложбине с относительной отметкой поверхности почвы $38,8 \mathrm{M}$.

Почвы, отнесенные к данной группе, каштановые и луговокаштановые карбонатные среднемощные и мощные глубоко-, слабо-, средне- или сильнозасоленные глинистые и тяжелосуглинистые, иногда щебнистые. Легкорастворимые соли отмечаются с глубины 180-200 см и ниже этого уровня. К ограниченно лесопригодным почвам мы отнесли также зональные слабосолонцеватые, солонцеватые и глубокозасоленные почвы, расположенные на склонах и днищах балок и оврагов.

Лугово-каштановые почвы имеют признаки гигроморфизма, которые проявляются в виде охристых и ржавых включений в почвообразующей породе, в солонцеватых почвах под горизонтом образуются сильно уплотненные иллювиальногумусовые и иллювиальные натриевые горизонты.

Описание почв овражно-балочного комп-лекса нами не приводится, их общая характерис-тика дана при описании группы лесопригодных почв.

Среди глубокозасоленных почв встреча-ются слабосмытые и щебнистые. Первые имеют укороченный гумусовый профиль, а вторые - обломки мергелей или кусков сопочной брекчии во всем профиле. Это продукты деятельности грязевых вулканов.

Содержание физической глины у рассматриваемых почв относительно однородно, легко- и среднеглинистые, также встречаются средне и тяжелосуглинистые и тяжелоглинистые разновидности. Распределение механических частиц по профилю равномерное, а в иллювиальных горизонтах солонцеватых почв отмечено увеличение содержания ила.

Определяющей связи между степенью засоления глубоких слоев почвообразующих пород и содержанием гумуса в верхних, перегнойноаккумулятивных горизонтах почв, ограниченно пригодных для выращивания древес-ных и кустарниковых растений, не отмечается. Это объясняется тем, что ме- 


\section{Природопользование}

жду корневыми системами и солевым горизонтом имеется некоторое пространство, которое позволяет развиваться естественной растительности. Поэтому при подборе лесных культур следует избегать выбора древесных видов с глубоким залеганием корневой системы, ограничивая тем самым глубину проникновения основной массы корней до 1,5 м.

Ограниченно лесопригодные почвы доста-точно обеспечены калием и значительно хуже- фосфором. У них высокая емкость поглощения, слабощелочная или щелочная реакция среды, большей частью насьщенная $\mathrm{Ca}^{2+}$. Степень на-сыщенности почвенного поглощающего комплекса натрием максимальна в иллювиальных солонцеватых почвенных горизонтах.

Отсутствие засоления связана с тем, что величина плотного остатка до глубины 180-190 см не превышает 0,3 \%, однако нижний уровень токсичности превышает предельно допустимые показатели.

При проектировании ландшафтных объектов строительства необходимо учитывать динамику содержания солей в почвах. В периоды осадков концентрация солей снижается, а также улучшается режим и глубина промывания горизонтов. В жаркие, аридные периоды происходит поднятие легкорастворимых солей к верхним горизонтам. Поэтому при планировании посадок лесных древесно-кустарниковых растений необходимо выбирать холодный и влажный период года. При подборе ассортимента древес-ных и кустарниковых видов, согласно экологическим условиям данной группы почв, учитывать их адаптивность к местным климатическим условиям.

Проанализированные почвы объединены в группу ограниченно пригодных для выращивания лесных культур. В этой связи на них удовлетворительно могут расти солестойкие древеснокустарниковые виды. Поэтому и долговечность посадок на них низкая, древесная продуктивность низкая. В связи с этим целесообразно создание насаждений защитного и озеленительного функционального назначения полосного, аллейного. Массивного или лесопаркового типов с применением высоких технологий и дополнительного увлажнения.

Для создания зеленых объектов в данных условиях перспективными древесными и кустар-никовыми видами представляются следующие: акация белая, гледичия трехколючковая, айлант высочайший, софора японская, ясень ланцетолистный и ясень обыкновенный, туя восточная, алыча, клен сахарный (сахаристый, серебристый), боярышник, аморфа кустарниковая, клен татарский, шелковица белая, акация желтая.

III группа - условно лесопригодные почвы. Эти местообитания характеризуются нарастанием засоленности и засушливости, что снижает потенциал их использования. В данную почвенно-типологическую группу объединены почвы, на которых даже наиболее солевыносливые виды деревьев находятся на крайнем пределе своего существования. По классификации Е.С. Мигуновой [8], сюда относятся особо и крайне сухие незасоленные, очень сухие с признаками засоленности, сухие и сырые слабозасоленные, свежие и влажные среднезасоленные местообитания, это почвы с глубиной залегания солей более 3 м в особо сухих, 2 м - в очень сухих, 1,5 м - в сухих и 1 м - в свежих и влажных условиях.

Из большого количества выделенных при картировании вариантов засоленных и солонце-ватых, щебнистых и смытых почв водоразделов и склонов балок и межгривных понижений в группу условно лесопригодных почв нами включены средне- и сильносолонцеватые незасоленные, среднесолонцеватоглубокосолончаковатые и просто глубокосолончаковатые виды каштановых и лугово-каштановых почв.

Их использование под выращивание лесных культур усложняется высокой степенью комплексности почвенного покрова сухой степи, так как в массивах основных почв пятнами залегают другие почвы, как правило, худшего качества, тем самым создавая сложную композицию почвенного покрова. Исходя из этого, каждый участок местности, планируемый под ландшафтное строительство, должен тща-тельно картироваться, чтобы оптимально ис-пользовать при композиционном размещении древесных, кустарниковых и травянистых видов разнообразие условий произрастания.

Почвы, которые входят в класс условно лесопригодных, характеризуются гораздо более низкой лесопригодностью по сравнению с ограниченно лесопригодными. Без мелиорации на них возможно выращивать наиболее засухоустойчивые и солевыносливые виды, при этом они в большинстве случаев без дополнительного увлажнения очень неустойчивы и недолговечны. Отведение земель этой категории под лесо- 


\section{Природопользование}

разведение может допускаться лишь в порядке исключения для создания насаждений специаль-ного, целевого назначения (озеленение баз отдыха, курортов и рекреаций). При этом небходимо предусматривать проведение дополни-тельных мероприятий, связанных с мелиорацией и орошением.

IV группа - почвы, пригодные для выращивания солеустойчивых кустарников. К ним, по классификации Е.С. Мигуновой [8], относятся крайне сухие слабозасоленные, свежие и влажные глубокосолончаковатые и солончаковатые почвы, а также сильно заболоченные (сырые) засоленные местообитания. Токсичные количества легкорастворимых солей в почвах этой группы находятся на глубинах 2,0-3,0 м в крайне сухих условиях, 1,5-2,0 м - в сухих, а у поверхности - в свежих, влажных и сырых.

Для выявления почвенно-литологических факторов выращивания кустарниковых видов в жестких условиях степи Таманского полуострова нами проведены исследования в естественных зарослях кустарников, местным населением названных «берестками» (табл. 5). Наиболее часто они встречаются на склонах или у подножия хребтов и, как отмечал И.С. Косенко [7], видимо, играли заметную роль в ландшафте девственной степи. Основными видами в этих зарослях являются: слива колючая, терн, вяз полевой (берест), бирючина обыкновенная, ежевика сизая, шиповник. Из травянистых растений большую роль играют высоко- стебельные виды: полынь обыкновенная, колокольчик рапунцулоевидный, головчатка трансильванская, цикорий обыкновенный, морковь дикая, живокость полевая, латук дикий, спаржа мутовчатая, пырей ползучий, подмаренник настоящий.

В настоящее время так называемые, берестковые насаждения подвергаются интенсив-ному антропогенному воздействию. В этих условиях сохранились только древесные виды, наиболее приспособленные к данному району: слива колючая, терн, ежевика и шиповник.

Жесткие условия среды, однако, не препятствуют произрастанию кустарниковых и травя-нистых растений. Так, здесь могут произрастать шиповник и боярышник. Кроме шиповника и боярышника, адаптированы злаковое разнотравье, луковичные дикоросы, полынь, кермек. Это связано со склоновым типом местности затенен-ных северных экспозиций. Поэтому условия рельефа и литологии важно учитывать при проектировании озелененных территорий.

Вышеизложенное позволяет рекомендовать закладку солевыносливых кустарниковых видов, так как в подобных условиях даже наиболее солевыносливые древесные породы выпадают до 10 лет после посадки. При сильной степени засоления на почвах данной группы может сравнительно устойчиво расти род Тамарикс. Ряд его видов, отличающихся высокой устойчивостью к засухе и высокому содержанию солей, ми-

Таблица 5

Критерии определения IV группы лесопригодности почв

\begin{tabular}{|c|c|c|c|c|c|}
\hline Название почв & $\begin{array}{c}\text { Степень } \\
\text { смытости }\end{array}$ & $\begin{array}{c}\text { Степень солон- } \\
\text { цеватости }\end{array}$ & $\begin{array}{c}\text { Степень солонче- } \\
\text { коватости }\end{array}$ & $\begin{array}{c}\text { Глубина } \\
\text { залегания } \\
\text { солей, м }\end{array}$ & $\begin{array}{c}\text { Минерализация } \\
\text { грунов вод, } \\
\text { г/л }\end{array}$ \\
\hline $\begin{array}{c}\text { Чернозёмы обык- } \\
\text { новенные и южные }\end{array}$ & $\begin{array}{c}\text { средне и } \\
\text { сильно }\end{array}$ & сильно & солончковатые & $1,0-1,5$ & $12-25$ \\
\hline $\begin{array}{c}\text { Лугово- } \\
\text { чернозёмные }\end{array}$ & сильно & солончковатые & $1,0-1,5$ & $12-25$ \\
\hline $\begin{array}{c}\text { Луговые } \\
\text { и каштановые }\end{array}$ & $\begin{array}{c}\text { сильне и } \\
\text { сильно }\end{array}$ & $\begin{array}{c}\text { глубоко солончко- } \\
\text { ватые }\end{array}$ & $0,5-1,0$ & $25-50$ \\
\hline $\begin{array}{c}\text { Лугово-каштановые } \\
\text { сильно }\end{array}$ & сильно & солончкоковатые & $1,0-1,5$ & $12-25$ \\
\hline $\begin{array}{c}\text { Светло-каштановые } \\
\text { и бурые }\end{array}$ & $\begin{array}{c}\text { средне и } \\
\text { сильно }\end{array}$ & сильно & $\begin{array}{c}\text { глубоко солончко- } \\
\text { ватые }\end{array}$ & $1,0-1,5$ & $12-25$ \\
\hline $\begin{array}{c}\text { Солонцы луговые } \\
\text { всех зон }\end{array}$ & сильно & $\begin{array}{c}\text { глубоко солончко- } \\
\text { ватые }\end{array}$ & $0,5-1,0$ & $25-25$ \\
\hline
\end{tabular}




\section{Природопользование}

рится с почвами, на которых другие древеснокустарниковые виды не формируют долговечные насаждения.

На менее засоленных сухих пространствах в сухой степи возможно произрастание засухо-устойчивых кустарников: терн, степная вишня, лох узколистный и серебристый, смородина золотистая, акация желтая, жимолость татарская.

Учитывая малую окупаемость лесных культур на таких землях и естественное стремление по возможности снизить издержки на их создание, избежать многократных дополнений и реконструкций, целесообразно на объектах, где предусматривается мелиорация и орошение, сразу отводить все наиболее засоленные участки под чистые посадки тамарикса, а на менее засоленных сухих позициях - и других кустарников. На таких землях они наиболее устойчивы и долговечны и выполняют защитную функцию, а также создают благоприятный микроклимат.

В данную почвенно-типологическую группу включаются и щебнистые виды солонце-ватых и засоленных почв северных склонов, в которых щебень выполняет мелиоративную функцию и улучшает лесорастительные свойства ландшафта.

V группа - нелесопригодные почвы. В эту группу входят наиболее засоленные, крайне сухие и сырые заболоченные местообитания. Они составляют 33 \% (940,7 га) отведенных под облесение земель Тамани. Большая часть их характеризуется почти полным отсутствием доступной для растений влаги, связанным либо с очень плохими физическими свойствами, препят-ствующими впитыванию атмосферных осадков, либо с высокой минерализацией почвенных растворов, что делает их недоступными даже для кустарниковых галофитов.

В степных солонцах, особенно корковых, доступная для растений влага имеется лишь в самом начале периода вегетации. Количество ее не превышает 3040 мм, что явно недостаточно для нормальной жизнедеятельности как древесной, так и травянистой растительности.

В солончаках и сильносолончаковатых почвах, формирующихся обычно при неглубоком залегании грунтовых вод и поэтому обильно увлажненных за счет их капиллярного подъема, бывают периоды сильного разбавления почвенных растворов атмосферны- ми, пресными водами, когда количество доступной влаги в них достигает значительных величин. Однако эти периоды кратковременны, и поэтому рост высшей растительности здесь также невозможен.

Граница лесопригодности этих почв определяется максимальными концентрациями их почвенных растворов и степенью солеустойчивости тех кустарниковых галофитов, которые на них возможно культивировать.

Также к полностью нелесопригодным относятся сильносолончаковые почвы бессточных межгривных синклиналей и котловин, где грунтовые воды не только высоко засолены, но и бессточны, поэтому корневые системы кустарни-ковых галофитов помимо воздействия токсичных веществ испытывают еще и вымокание.

Засушливость климата степи Тамани определяет более слабый сток, нежели в лесных ландшафтах, меньшее значение центра и прямых нисходящих водных связей, большую роль обратных бионосных связей в почвах, менее совершенное геохимическое сопряжение внугри автономного ландшафта и между автономными и подчиненными ландшафтами, а также развитие испарительной концентрации элементов. При засолении ухудшаются условия существования большинства биоорганизмов, уменьшается ежедневная продукция живого вещества. По влиянию на биологический круговорот засоление почв сопоставимо с их иссушением.

Вместе с засолением происходит и обратный процесс - рассоление. Оба процесса характерны для исследуемой территории, часто они происходят в пределах одного геохимичес-кого ландшафта. Рассоление происходит постепенно и образует особую серию ландшафтов, начальным членом которой является засоленный ландшафт (межгривные котловины), а последним - незасоленный (элювиальные позиции). К промежуточным членам серии изменений относятся ландшафты, в которых соли сохранились лишь в средних и нижних горизонтах почв и пород (склоны гряд, отдельных увалов и гор). Эта закономерность положена нами в основу классификации почв Таманского стационара по их пригодности к выращиванию и, именно она должна в первую очередь учитываться при размещении древесно-кустарниковых видов и трав при архитектурном ландшафтном строительстве в этом природно-уникальном районе. 


\section{Природопользование}

\section{Библиографический список}

1. Белюченко, И. С. Темрюкский район как особое историко-культурное и природно-климатическое образование [Текст] / И. С. Белюченко // Экологические проблемы Кубани. Темрюкский район : сб. науч. тр. НИИ экологии КубГАУ, № 15. - Краснодар, 2002. - С. 3-7.

2. Власенко, В. П. Влияние динамики агроэкологических показателей почв Азово-Кубанской низменности на их агропроизводственную ценность и кадастровую стоимость [Текст] / В.П. Власенко, 3. Р. Шеуджен // Политематический сетевой электронный научный журнал Кубанского государственного аграрного университета (Научный журнал КубГАУ) [Электронный ресурс]. - Краснодар, 2017. - № 09(133). С. 718-729. - Режим доступа: http://ej.kubagro.ru/2017/09/pdf/54.pdf.

3. Волков, Ф. И. Перспективы создания озеленительных насаждений на приморских ракушечных песках [Текст] / Ф. И. Волков, Е. С. Мигунов // Лесное хозяйство. - 1969. - № 11. - С. 32-33.

4. Зонн, С. В. Горно-лесные почвы Северо-Западного Кавказа [Текст] / С. В. Зонн. - М., Л. : Изд-во АН CCCP, 1950. - 38 c.

5. Зонн, С. В. Проблемы лесного почвоведения и современные методы лесорастительной оценки почв [Текст] / С. В. Зонн, Л. О. Карпачевский // Почвоведение. - 1987. - № 9. - С. 30-33.

6. Карпачевский, Л. О. Лес и лесные почвы [Текст] / Л. О. Карпачевский. - М. : Лесн. пром-сть, 1981. $263 \mathrm{c}$.

7. Косенко, И. С. К познанию растительности Таманского полуострова [Текст] / И. С. Косенко // Тр. КСХИ. - Краснодар, 1927. - № 5. - С. 15-21.

8. Мигунова, Е. С. Методические указания по лесотипологическому обследованию засоленных земель [Текст] / Е. С. Мигунова. - Харьков, 1974. - 34 с.

9. Changes in the composition and balance of humus in agricultural use of leached chernozem in the AzovKuban lowland [Text] / V. I. Terpelets, Yu. S. Plitin', A. V. Buzoverov, A. P. Maksimenko // Works of the Kuban State Agrarian Univercity. 2015. - Vol. 4. - P. 63-70.

10. Maksimenko, A. P. Solving the ecological problems of sand-coquina landscapes in the eastern sea of Azov region by means of afforestation [Text] / A. P. Maksimenko // Russian Journal of Ecology. - 2003. - Vol. 34. - Iss. 5. P. 355-358.

11. Specific Aspects of Creating a Sustainably Functioning Ecosystem of an Organic Apple Garden in the South of Russia [Text] / T. N. Doroshenko, G. F. Petrik, S. S. Chumakov, S. B. Krivorotov, A. P. Maksimenko // J. Pharm. Sci. \& Res. - 2018. - Vol. 10(7). - P. 1652-1655.

12. The geography of Vertisols and Vertic soils in the Kuban-Azov Lowland [Text] / N. B. Khitrov [et al.] // Eurasian Soil Science. - 2015. - T. 48. - № 7. - P. 671-688.

\section{References}

1. Beluchenko I. S. Temrukskiy raion kak osoboe istoriko-kulturnoe I prirodno-klimaticheskoe obrazovanie [Temryuk district as a special historical, cultural and natural-climatic formation]. Ecologicheskie problem Kubani. Temrukskyi raion: Sb. NII ecologii KubGAU [Ecological problems of the Kuban. Temryuk district: Collected papers of Research Institute of ecology KubGAU]. Krasnodar, 2002, pp. 3-7. (In Russian)

2. Vlasenko V. P., Sheudzhen Z. R. Vliyanie dinamiki agroekologicheskih pokazateley pochv Azovo-Kubanskoy nizmen-nosti na ih agroproizvodstvennuyu tsennost $i$ kadastrovuyu stoimost [Influence of dynamics of agroecological indicators of soils of the Azov-Kuban lowland on their agricultural production value and cadastral value] Politematicheskiy setevoy elektronnyiy nauchnyiy zhurnal Kubanskogo gosudarstvennogo agrarnogo universiteta (Nauchnyiy zhurnal KubGAU) [Polytechnical network electronic scientific journal of the Kuban State Agrarian University (KubSAU Scientific Journal)]. Krasnodar, 2017, no 09(133), pp. 718-729. Available at: http://ej.kubagro.ru/2017/09/pdf/54.pdf(In Russian)

3. Volkov F. I., Migunov E. S. Perspektivyi sozdaniya ozelenitelnyih nasazhdeniy na primorskih rakushechnyih pes-kah [Prospects for creating greenery plantations on seaside shell sands] Lesnoe hozyaystvo [Forestry], 1969, no 11. 


\section{Природопользование}

pp. 32-33. (In Russian)

4. Zonn S. V. Gorno-lesnyie popochvyi Severo-Zapadnogo Kavkaza [Mountain-forest soils of the North-Western Caucasus] Moscow, Leningrad, 1950, 38 p. (In Russian)

5. Zonn S. V., Karpachevskiy L. O. Problemyi lesnogo pochvovedeniya i sovremennyie metodyi lesorastitelnoy otsenki pochv [Problems of forest soil science and modern methods of forest soil evaluation] Pochvovedenie [Soil Science], 1987, no 9, pp. 30-33. (In Russian)

6. Karpachevskiy L. O. Les i lesnyie pochvyi [Forest and forest soils]. Moscow, 1981, 263 p. (In Russian)

7. Kosenko I. S. K poznaniyu rastitelnosti Tamanskogo poluostrova [To the knowledge of the vegetation of the Taman Peninsula] Works of KSHI, Krasnodar, 1927, no 5. (In Russian)

8. Migunova E. S. Metodicheskie ukazaniya po leso-tipologicheskomu obsledovaniyu zasolennyih zemel [Methodological instructions for forest typological examination of saline lands] Harkov, 1974, 34 p. (In Russian)

9. Terpelets V. I., Plitin Yu. S., Buzoverov A. V., Maksimenko A. P. Changes in the composition and balance of humus in agricultural use of leached chernozem in the Azov-Kuban lowland. Works of the Kuban State Agrarian Univercity, Vol. 4, 2015, p. 63-70.

10. Maksimenko A. P. Solving the ecological problems of sand-coquina landscapes in the eastern sea of Azov region by means of afforestation Russian Journal of Ecology, 2003, Vol. 34, Iss. 5, pp. 355-358.

11. Doroshenko T. N. [et al.] Specific Aspects of Creating a Sustainably Functioning Ecosystem of an Organic Apple Garden in the South of Russia. J. Pharm. Sci. \& Res. Vol. 10(7), 2018, pp. 1652-1655.

12. Khitrov N. B. [et al.] The geography of Vertisols and Vertic soils in the Kuban-Azov Lowland. Eurasian Soil Science. 2015, Vol. 48, no 7, pp. 671-688.

\section{Сведения об авторах}

Максименко Анатолий Петрович - профессор кафедры плодоводства ФГБОУ ВО «Кубанский государственный аграрный университет имени И.Т. Трубилина», доктор сельскохозяйственных наук, г. Краснодар, Российская Федерация.

Дзябко Евгений Петрович - доцент кафедры плодоводства ФГБОУ ВО «Кубанский государственный аграрный университет имени И.Т. Трубилина», кандидат сельскохозяйственных наук, г. Краснодар, Российская Федерация.

Максимизов Денис Витальевич - консультант управления растениеводства министерства сельского хозяйства и перерабатывающей промышленности Краснодарского края, кандидат сельскохозяйственных наук, г. Краснодар, Российская Федерация.

\section{Information about authors}

Maksimenko Anatoly Petrovich - Professor of the Department of Fruit Growing, Federal State Budget Education Institution of Higher Education «Kuban State Agrarian University named after I.T. Trubilin», DSc (Agriculture), Krasnodar, Russian Federation.

Dzyabko Evgeny Petrovich - Associate Professor of the Fruit Growing Department, Federal State Budget Education Institution of Higher Education «Kuban State Agrarian University named after I.T. Trubilin», PhD (Agriculture), Krasnodar, Russian Federation.

Maksimtsov Denis Vitalievich - Consultant of the Plant Management Department of the Ministry of Agriculture and Processing Industry of Krasnodar Region, PhD (Agriculture), Krasnodar, Russian Federation. 